\title{
Mother's Profile and the Infant and Underfive Mortality in Marunda North Jakarta
}

\author{
Titi Sunarwati Sularyo
}

\begin{abstract}
Abstrak
Telah dilakukan stiatu penelitian prospektif pada 102 balita dari keseluruhan jumlah 500 balita di Marunda Jakarta Utara. Fokus penelitian adalah profil ibu (corak reproduksi dan pendidikan) serta riwayat kematian balita dalam keluarga. Terdapat ketidaksesuaian antara persepsi ibu tentang corak reproduksi dengan penerapannya, dalam arti meskipun 55\% ibu tersebut telah mempunyai persepsi yang baik corak reproduksi namun penerapan perilakunya yang sesuai hanya ditemukan pada 5.9\%. Ditemukan bahwa corak reproduksi ibu (terutama aspek paritas dan usia ibu saat melahirkan anak pertama) secara bermakna berhubungan dengan mortalitas balitanya; makin tinggi paritas dan makin muda usia ibu makin besar kemungkinan angka kematian balitanya. Demikian juga ditemukan bahwa pendidikan ibu yang kurang meningkatkan kematian balita. Dengan memperbaiki pendidikan ibu dari buta huruf menjadi sekolah dasar (tamat maupun tidak) kematian balita dapat diturunkan tiga perempatnya. Sangat disayangkan bahwa kedua aspek profil ibu tersebut masih sangat kurang. Dengan demikian tidaklah mengherankan bahwa angka kematian bayi serta balita pada keluarga tersebut masih tinggi (99.7 dan 154 per 1000 lahir hidup) dibandingkan dengan angka kematian bayi serta balita umumnya di Indonesia (58 dan 120 per 1000 lahir hidup).
\end{abstract}

\begin{abstract}
A prospective study has been conducted on 102 underfives in Marunda, North Jakarta. The Focus of investigation was the mother's profile (reproductive pattern and schooling) and the underfive mortality. A discrepancy was found between the mother's perception and her adoption of the reproductive pattern, in the sense that although $55 \%$ of mothers had a good perception on reproduction, behavioural adoption was only 5.9\%. Furthermore the mother's reproduction pattem (especially the number of siblings and the age at first child birth) was significantly related to the underfive deaths. Mother's schooling was also very significantly related to the underfive mortality. It was also revealed that by improving the mother's schooling from illiteracy to elementary schooling the underfive mortality could be reduced by three quarters. So it was very unfortunate that those two aspects of mother's profile were still unsatisfactory. Thus it was not surprising that the infant mortality and underfive mortality figures in the families of the children under study were still high compared to the general figures in Indonesia (99.7 vs 58 per 1000 livebirths and 154 vs 120 per 1000 livebirths, respectively).
\end{abstract}

Keywords: Mother's reproductive pattern, mother's schooling, infant mortality, underfive mortality.

\section{INTRODUCTION}

The health of the mother has a tremendous impact on her child's growth and development especially the underfives. One of the most important determinants of a mother's health and thus considered as an aspect of her profile in terms of her child's wellbeing, is her reproductive pattern. A mother with an unfavorable reproductive pattern, i.e., giving birth at a too young age, too close intervals of births and too many births results in an unfavorable physical as well as psychosocial health so that she may not be able to create a good

Department of Child Health University of Indonesia Medical School quality rearing practice for her young. Nevertheless one must take in mind that the parameter of reproduction is also related to socio-economic and cultural factors, for instance a high parity, goes along with low socioeconomic conditions, undernutrition, unhygienic situation, overcrowding, low education and resistence to changes in attitudes. Another aspect of a mother's profile is her schooling. Many researchers are of the opinion that mother's schooling is closely related to the mortality of her offsprings. ${ }^{2,3,4}$

Infant and underfive mortality are by many writers considered as important and sensitive indicators in reflecting the health and socio-economic welfare of a certain community. ${ }^{2,4}$ In Indonesia the figures of the infant mortality rate (IMR) and the underfive mortality 
rate (U5MR) are still high, i.e., 58 per 1000 livebirths and 120 per 1000 livebirths respectively. The government plans to reduce the IMR from 98 per 1000 livebirths in 1980 to 45 per 1000 livebirths in year 2000, and referring to the RP3JPK (the Long-term National Health Plan) it is hoped to obtain the target of IMR of 35 per 1000 livebirths by the year 2000 .

This study aims to find out the underfive mortality in the studied families and its relationship to the mother's profile (reproductive pattern and schooling).

\section{MATERIALS AND METHODS}

This is a prospective study, performed in 1986 in Marunda, North Jakarta by making home visits to families having underfive children. The selection of families was done at random. The home visits consisted of interviewing the mothers, overviewing the house, and examining the child.

All data obtained were filled in specially designed questionnaire. The data collected included mother's reproductive pattern (age at birth of child, interval of birth, and number of children), mother's schooling, usage of contraceptive, family income, underfive mortality in the family, child's rearing practice, and the child's growth and development.

\section{Data recording and analysis}

After having been coded and edited, the data of the home visits were statistically analyzed at the Community Medicine Data Analysis Laboratory, University of Indonesia Medical School. Out of the quantitative data the mean values and standard deviations were found out. Hypotheses testing by chi-square test were also performed to compare the groups. A p value of $0.05(5 \%)$ was considered as significant while a p value of $0.01(1 \%)$ as very significant. For analyzing the multiple influences of various independent variables, multiple regression analysis was made by using the stepwise approach of the standard statistical formula.

\section{RESULTS AND DISCUSSIONS}

Marunda was a densely populated rural coastal area about $30 \mathrm{~km}$ away from Jakarta. The total population was approximately 5000 people, $40 \%$ were under the age of 15 years, with around 500 underfives. The total area was 7.46 square $\mathrm{km}$ thus the population density was 760 people per square $\mathrm{km}$. There were many fish ponds owned by the so called "juragans" or landlords who lived in the Jakarta city.
Most of the mothers under study were housewives, $88.3 \%$ of them had low education (illiterate and elementary schooling). Most of the fathers were fishermen working as laborers at the fish ponds they did not own themselves. The family income was low, averaging at Rp.13,287 per capita per month.

There were all in all 110 underfive documents obtained. Seven documents were not complete and another one was of a 40 days old baby. All these eight were excluded from this study leaving 102 underfives to be further analyzed. These 102 children consisted of 43 girls (42.2\%) and 59 boys (57.8\%).

Table 1. Distribution of studied children by age

\begin{tabular}{ccc}
\hline Age (months) & No & Percentage \\
\hline $6-$ & 19 & 18.8 \\
$12-$ & 24 & 23.5 \\
$24-$ & 16 & 15.8 \\
$36-$ & 29 & 28.4 \\
$48-<60$ & 14 & 13.7 \\
\hline Total & & \\
\hline
\end{tabular}

The mean age of the children studied was 31.8 (SD 16.3) months thus belonging to the ideal age group (12-36 months) for underfives to be investigated in terms of their growth and development and factors related to them. ${ }^{3}$

\section{Mother's reproductive pattern}

Table 2 shows that although $54.9 \%$ of mothers had a good perception of reproductive pattern, only 6 mothers $(5.9 \%)$ adopted it. In other words $54.9 \%$ of mothers knew what is right about reproductive pattern but only $5.9 \%$ of them behaved accordingly. So there seemed to be a discrepancy between knowing and behaving (perception and adoption).

Table 2. distribution of mothers of studied children by their reproductive pattern and reproductive perception

\begin{tabular}{lcc}
\hline & No & Percentage \\
\hline Reproductive pattern : & & \\
good (score 5-6)* & 6 & 5.9 \\
poor (score 0-4) & 96 & 94.1 \\
Reproductive perception & & \\
good (score 5-6) & 56 & 54.9 \\
poor (score 0-4) & 46 & 45.1 \\
\hline
\end{tabular}

* Reproductive pattem scoring : 
Maternal score by age at first birth

\begin{tabular}{cc}
\hline Matemal age (yrs) & Score \\
\hline$<18$ & 0 \\
$18-$ & 1 \\
$20-$ & 2 \\
$31-$ & 1 \\
$\geq 35$ & 0 \\
\hline
\end{tabular}

Maternal score by interval

\begin{tabular}{cc}
\hline Interval (yrs) & Score \\
\hline$<2$ & 0 \\
$2-$ & 1 \\
$3-$ & 2 \\
$\geq 4$ & 1 \\
\hline
\end{tabular}

Maternal score by parity

\begin{tabular}{cc}
\hline No of children & Score \\
\hline $1-3$ & 2 \\
$4-5$ & 1 \\
$\geq 6$ & 0 \\
\end{tabular}

This finding was also reflected by the fact that only 40 mothers $(39.2 \%)$ were contraceptive users of which 3 mothers $(7.5 \%$ of 102$)$ had been sterilized (Table 3 ).

Table 3. Distribution of mothers by usage of contraceptives

\begin{tabular}{|c|c|c|c|c|}
\hline & & & No & Percentage \\
\hline \multicolumn{3}{|l|}{ Non users } & 62 & 69.8 \\
\hline \multicolumn{3}{|c|}{ Users, type of contraceptive : } & 40 & 39.2 \\
\hline IUDs & 3 & $7.5 \%$ & & \\
\hline Pills & 12 & $30.0 \%$ & & \\
\hline Shots & 22 & $55.0 \%$ & & \\
\hline Sterilized & 3 & $7.5 \%$ & & \\
\hline Total & 40 & $100.0 \%$ & & \\
\hline
\end{tabular}

The existence of a discrepancy between knowledge and behaviour should be seriously taken in mind so as to overcome it when planning health education programs on family planning.

The findings of the low scores of the reproductive patterns of mothers (Table 2) was in accordance also with the fact that in this study the mean ages of mothers getting married and giving birth to their first child were very young, 15.0 (SD 2.9) years and $17.5 \pm 3.4(\mathrm{SD})$ years respectively, the number of children were high namely 4.5 (SD 2.7), and the birth intervals were relatively close i.e. 29.5 (SD 14.6) months. All these were also related to the low socio-economic condition of the overall population in Marunda.

Table 4. Reproductive pattern of mothers of studied children

\begin{tabular}{lc}
\hline Reproductive pattern & Mean (SD) \\
\hline Age at marriage (yrs) & $15.0(2.9)$ \\
Age at first child birth (yrs) & $17.5(3.4)$ \\
Number of children (parity) & $4.5(2.7)$ \\
Birth intervals (months) & $29.5(14.6)$ \\
\hline
\end{tabular}

Taking into account the concept of a small, happy and prosperous family (NKKBS) and if we really desire to reach it, a great job and endeavor have still to be done. In a previous report it was revealed that the mother's reproductive pattern was a partial contributor to the child's linear growth and immunization state. Thus indeed the mother's reproductive pattern played an important role in constituting the child's growth and health.

\section{Mother's schooling}

Many authors are of the opinion that child mortality largely depends on a mother's proper schooling, in a sense that she is not illiterate: knows how to read and write, understands numbers, and has basic knowledge. $2,3,6,7$

By having proper schooling a mother will find it easier to digest and so accept the messages given in various kinds of methods and media around her about healthful living behaviors, for her and her family, including her offsprings.

This study reveals that mother's schooling was statistically related to the child's development state ( $p<$ $0.05)$ and the underfive mortality ( $p<0.01)$ (Table 5).

Table 5. Distribution of mother's schooling by related factors of statistical significance

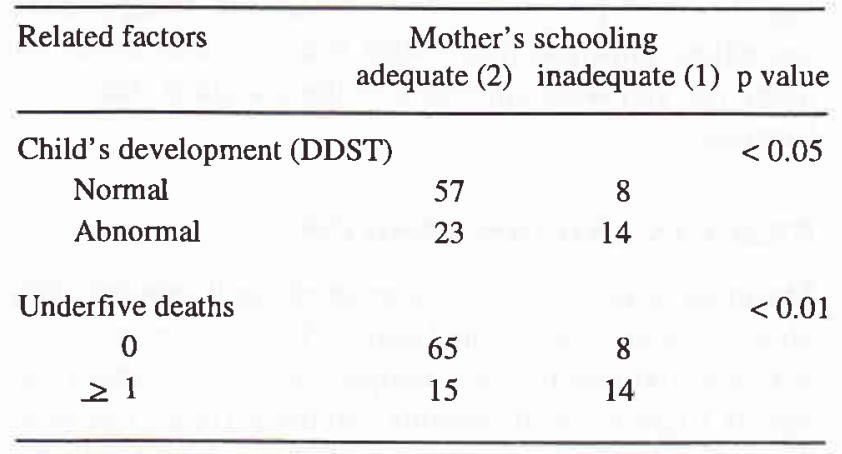

DDST : Denver Development Screening Test

(1) : illiterate

(2) : elementary \& over 
Table 6. Distribution of mothers by type of schooling

\begin{tabular}{lrc}
\hline Type of schooling & No & Percentage \\
\hline No schooling at all & 22 & 21.6 \\
Elementary & 68 & 66.7 \\
Junior high & 9 & 8.2 \\
Senior high & 3 & 2.9 \\
Higher education & - & - \\
\hline Total & 102 & 100.0 \\
\hline
\end{tabular}

There were a great enough number of mothers $(21.6 \%)$ who were completely illiterate. Thus this might be a serious hindrance for the survival of the child.

Table 7. Distribution of families with underfive deaths by number of underfives in the family

\begin{tabular}{|c|c|c|}
\hline & No of family with U5M & Percentage \\
\hline \multicolumn{3}{|c|}{ No of underfives in family } \\
\hline 1 underfive & 14 & 48.3 \\
\hline 2 underfives & 10 & 34.5 \\
\hline$>2$ underfives & 5 & 17.2 \\
\hline Total 29100.0 & & \\
\hline
\end{tabular}

U5M : underfive mortality

Table 8. Distribution of underfive death by demographic age group

\begin{tabular}{lc}
\hline Age group & No of underfive deaths \\
\hline $0-7$ days & 14 \\
$0-28$ days & 26 \\
$0-12$ months & 33 \\
$0-60$ months & 51 \\
\hline
\end{tabular}

Table 7 and 8 show that there were 29 families with underfive deaths with a total of 51 underfive deaths. So on the average in one family there occurred 1.8 underfive deaths. This figure was high enough and might unconsciously be the reason for them to raise their fertility as a consequence of the desire to have more children to replace those that could not have survived. Meanwhile furthermore in this study it will be revealed that raising fertility would significantly increase the underfive mortality instead. It was also not surprising that the average family size in this study was 6.5 (SD 2.4) people, much above the actual figure of 4.6 for Indonesia. ${ }^{8}$
The average number of underfives in a family was also high, namely 2.0 (SD 0.7) (Table 9). This might also be a reflection of the answers given by the families about child value where 99 mothers (97\%) considered that the value of their child was that it brings along with it luck and blessing to the family and later on also to take care of the parents in old age (Table 10).

Table 9. Distribution of families with underfives by number of underfives per family

\begin{tabular}{ccc}
\hline No of underfives per family & No of family & Percentage \\
\hline 1 & 25 & 24.5 \\
2 & 50 & 49.0 \\
$\geq 3$ & 27 & 26.5 \\
\hline Total & 102 & 100.0 \\
\hline
\end{tabular}

Table 10. Child value, mother's view

\begin{tabular}{lrc}
\hline Value & No & Percentage \\
\hline Luck \& blessing & & \\
Caretaker in old age & 99 & 97.0 \\
Indiference & 3 & 3.0 \\
\hline Total & 102 & 100.0 \\
\hline
\end{tabular}

As was mentioned before the average number of underfives in a family was 2 underfives per family. This condition would make the mother very busy and overoccupied in raising their young and take care of the other members of the family also so that she would have little time for herself. This will also indirectly tend to heighten the risk of mortality.

From Table 8 and the fact that there were all 331 livebirths and one stillbirth, the following figures in terms of the sample population mortalities can be concluded :

Perinatal mortality rate 45.2 per 1000 births Early neonatal mortality rate 42.3 per 1000 livebirths (first week mortality rate)

Neonatal mortality rate 75.5 per 1000 livebirths Post neonatal mortality rate 24.2 per 1000 livebirths Infant mortality rate 99.7 per 1000 livebirths Underfive mortality rate 154 per 1000 livebirths or 102 per 1000 underfives.

The infant mortality and the underfive mortality rates are usually considered as important and sensitive indicators of the health and socio-economic welfare of a 
certain community. ${ }^{2,4}$ From these datas it is obvious that the mortality rates especially the infant and underfive mortality rates are much higher than the general figures in Indonesia which are 58 per 1000 livebirths and 120 per 1000 livebirths respectively.

Table 11. Distribution of mortality by probable cause of death

\begin{tabular}{lcc}
\hline Probable cause & No of mortality & Percentage \\
\hline Diarrhea & 5 & 9.8 \\
Measles & 4 & 7.8 \\
CNS infection & 3 & 5.9 \\
ARI & 2 & 3.9 \\
Accidental drowning & 2 & 3.9 \\
Tetanus & 1 & 2.9 \\
DHF & 1 & 2.9 \\
Fever & 23 & 45.1 \\
Not clear & 10 & 19.6 \\
\hline Total & 51 & 100.0 \\
\hline
\end{tabular}

CNS : Central Nervous System

ARI : Acute Respiratory tract infection

DHF : Dengue hemorrhagic fever

Table 12. Main causes of death in underfives, HHS 1986 and $1992^{11}$

\begin{tabular}{ll}
\hline Source & Cause of Death \\
\hline HHS 1986 & ARI \\
& Tetanus \\
& Perinatal problems \\
& Diarthea \\
& CNS infection \\
& Diarrhea \\
HHS 1992 & ARI \\
& Diphteria-Pertussis-Measles \\
& Trauma-Poisoning-Accidents \\
& Malaria \\
\hline
\end{tabular}

HHS : Health Household Survey

ARI : Acute Respiratory tract infection

CNS : Central Nervous System

In Many cases (19.6\%) causes of death are still unclear. Most of the deaths (76.5\%) were caused by infection although in part of it only fever were mentioned as probable cause (Table 11). This pattern was not very different from the pattern of the causes of deaths in underfives in Indonesia (see Table 12).

Cross tabulation between the underfive mortality and its influencing factors (Table 13) revealed that factors that had significant influence on the underfive mortality were :

1. Mother's schooling $(\mathrm{p}<0.01)$

2. Utilization of the KMS (road to health card) $(\mathrm{p}<$ 0.01 )

3. Mother's parity or number of children $(\mathrm{p}<0.05)$

4. Age of mother at first child birth $(\mathrm{p}<0.05)$

Table 13. Distribution of underfive mortality by influencing factors

\begin{tabular}{|c|c|c|c|}
\hline \multirow[t]{2}{*}{ Factors } & \multicolumn{2}{|c|}{ Underfive mortality } & \multirow[b]{2}{*}{$\mathrm{p}$ value } \\
\hline & Non/- & Present/+ & \\
\hline Mother's education & & & $<0.01$ \\
\hline illiterate & 8 & 14 & \\
\hline elementary \& over & 65 & 15 & \\
\hline Mother's reproduction & & & \\
\hline - Parity & & & $<0.05$ \\
\hline $1-3$ & 39 & 7 & \\
\hline $4 \&$ over & 34 & 29 & \\
\hline - Age at first birth (yrs) & & & $<0.05$ \\
\hline$\leq 17$ & 46 & 26 & \\
\hline$>17$ & 27 & 3 & \\
\hline - Birth interval (yrs) & & & $>0.05$ \\
\hline$<2$ & 12 & 7 & \\
\hline $2-$ & 37 & 14 & \\
\hline $3-$ & 9 & 7 & \\
\hline$>4$ & 5 & 1 & \\
\hline - Reproductive score & & & $>0.05$ \\
\hline $0-4$ & 64 & 29 & \\
\hline $5-6$ & 6 & 0 & \\
\hline Immunization state & & & $>0.05$ \\
\hline good (complete) & 13 & 7 & \\
\hline poor (incomplete) & 60 & 22 & \\
\hline KMS utilization & & & $<0.01$ \\
\hline good (weight curve +) & 17 & - & \\
\hline poor (incomplete) & 56 & 22 & \\
\hline Breastfeeding & & & $>0.05$ \\
\hline good (exclusive) & 60 & 26 & \\
\hline poor & 13 & 3 & \\
\hline Morbidity & & & $>0.05$ \\
\hline seldom $(1-3 \mathrm{x} / \mathrm{yr})$ & 27 & 12 & \\
\hline frequent $(>3 \mathrm{x} / \mathrm{yr}$ ) & 46 & 17 & \\
\hline
\end{tabular}

\section{Underfive mortality and mother's schooling}

It has been stated that mother's schooling has tremendous impact on her underfive's death. 
Table 14. Distribution of underfive mortality by mother's schooling in detail

\begin{tabular}{lrrrr}
\hline Mother's schooling & \multicolumn{2}{c}{ Mortality } & Total & p value \\
& - & + & & \\
\hline Illiterate & 8 & 14 & 22 & $<0.01$ \\
Elementary & 57 & 11 & 68 & \\
Junior high & 5 & 4 & 9 & \\
Senior & 3 & - & 3 & \\
\hline Total & 73 & 29 & 102 & \\
\hline
\end{tabular}

This table shows that in the illiterate mothers group the underfive mortality was very significantly higher than in literate mothers i.e. $63.6 \%$ vs $18.8 \%$. Thus it could be said that by just raising mother's schooling from being illiterate to elementary schooling (completed or even uncompleted) the mortality could be reduced to a quarter of it $(63.6 \%$ to $16.2 \%)$. These findings were also in accord with those of Utomo. ${ }^{2}$

\section{Underfive mortality and mother's reproductive pattern}

\section{Number of siblings (parity)}

Table 15. Detailed distribution of underfive mortality by number of siblings

\begin{tabular}{crrrl}
\hline No of siblings & \multicolumn{2}{c}{ Mortality } & Total & p value \\
& - & + & & \\
\hline $1-3$ & 39 & 7 & 46 & $<0.05$ \\
$4-5$ & 19 & 10 & 29 & \\
$6+$ & 15 & 12 & 27 & \\
\hline Total & 73 & 29 & 102 & \\
\hline
\end{tabular}

Mothers with $1-3$ siblings had a significantly ( $\mathrm{p}<$ 0.05 ) lower underfive death than those with $\geq 4$ siblings (Table 15). In mothers with 1-3 siblings the proportion of underfive death was $15.2 \%$ while in those with $\geq 4$ the proportion became $39.3 \%$ meaning it rose 2.5 times. Even in mothers with $\geq 6$ siblings the proportional mortality was almost 3 times higher than in mothers with 1-3 children (Table 15).

A high parity will raise the morbidity and mortality risks for the mother as well as the child. For the child a raise in mother's parity (more than 3 and especially more than 5) will very obviously increase fetal, perinatal, and infant deaths besides increasing the morbidity also, especially concerning the gastrointestinal and respiratory tracts, (among others, as a consequence of overcrowding) and malnutrition (as a result of a reduced per capita consumption unit). This situation will be aggravated by the vicious cycle of infectious diseases and malnutrition and it even often ends in death. $1,7,9$

\section{Age of mother at first birth}

Table 16. Detailed distribution of underfive death by age of mother at first birth

\begin{tabular}{ccccc}
\hline Age of mother (yrs) & \multicolumn{2}{c}{ Mortality } & Total & p value \\
& - & + & & \\
\hline$<15$ & 9 & 9 & 18 & \\
$15-17$ & 37 & 17 & 54 & $<0.05$ \\
$18-20$ & 19 & - & 19 & \\
$21-30$ & 8 & 3 & 11 & \\
\hline
\end{tabular}

Mothers giving her first birth at the age of $>17$ years had significantly lower underfive deaths than those at younger ages (Table 16). In the literature ${ }^{1,7,9}$ it was said that a mother too young at age when delivering her first child will raise the morbidity and mortality risks for the mother as well as the offsprings.

\section{Birth intervals}

Table 17. Detailed distribution of underfive death by birth interval

\begin{tabular}{crrrr}
\hline Interval (yrs) & \multicolumn{2}{c}{ Mortality } & Total & p - vlaue \\
& - & + & & \\
\hline 1 & 2 & 2 & 4 & \\
2 & 22 & 9 & 31 & \\
$\leq 3$ & 33 & 17 & 50 & \\
$\geq 3$ & 16 & 1 & 17 & \\
\hline Total & 73 & 29 & 102 \\
\hline
\end{tabular}

Though Table 17 shows no significant relationship between deaths and intervals but there was a tendency that the closer the interval the higher the underfive mortality: at an interval of $\leq 1$ year, the proportional mortality was $50 \%$; when the interval was $2-3$ years the proportional death became $32.1 \%$ and when the interval was $>3$ years the proportional death became $5.9 \%$. Joseph Beasly as cited by Sularyo concluded that babies with close birth intervals $(<1$ year) with the previous child experienced a mortality risk 1.5 times 
higher than when the interval was $\geq 2$ years. ${ }^{9}$ Many authors were also of about the same opinions. ${ }^{10,12}$ Close birth intervals are usually related to improper early weaning practices (in terms of hygiene and kind and quality of preparation of the milk formula) which will in turn enhance the occurrence of diarrheal diseases and malnutrition. Short birth intervals were also said to be related to low birth weights. For the mother short birth intervals will prevent from recuperating completely after every pregnancy, delivery and lactation leading indirectly to an inappropriate rearing practice for her children.

Referring to Table 13 though there was no significant relationship between mortality and mothers reproductive score, there was an impression of a tendency that the better the reproductive pattern (higher score of reproduction) the lower the mortality, and mothers with good reproductive patterns (score 5-6) had no underfive mortality at all.

Table 13 also shows that the underfive deaths were very significantly $(p<0.01)$ related to the KMS utilization. Families with good KMS utilization (all of the 17 families with no underfive deaths at all) seemed to have adopted the healthful living behaviour and regularly (and periodically) took the children for weighing and examination to the health worker so that no underfive death occurred at all.

The multiple regression analysis of the occurrence of the underfive mortality by the eight related factors also revealed that the underfive mortality comprised partially $40 \%$ by mother's poor schooling and partially $24 \%$ by the poor KMS utilization respectively when the other factors were held constant. All these findings supported the other findings analyzed before.

This study also showed that the mother played a very important role in the child's wellbeing and growth and development as it was revealed that the mother was the sole and prime child caretaker (91.2\%). See Table 18.

Table 18. Role of mother in child rearing practice of studied children

\begin{tabular}{lrc}
\hline Child rearing practice & No & Percentage \\
\hline Sole caretaker & & \\
mother & 98 & 96.1 \\
grandmother & 4 & 3.9 \\
Total & 102 & 100.0 \\
Decision maker & & \\
mother & 93 & 91.2 \\
father & 6 & 5.9 \\
both & 3 & 2.9 \\
\hline Total & 102 & 100.0 \\
\hline
\end{tabular}

Thus referring to her vital role just mentioned before, it seem crucial to promote the quality of mother's profile that is to say, her schooling and reproductive pattern.

\section{CONCLUSIONS}

Out of this study several conclusion were made, as follows

- The mother's profile (reproductive pattern and schooling) was still unsatisfactory

- There was a discrepancy betwen mother's perception and her adoption of reproduction

- The higher the mother's parity and the younger the mother's age at first birth the higher also will be the underfive mortality

- A poor schooling of the mother (illiteracy) will increase the underfive mortality

- A good schooling of a mother will improve her underfive development

- The underfive mortality was influenced by the mother's schooling, the KMS utilization and the mother's reproductive pattern (especially parity and age at first child birth)

- Almost all mothers were sole caretakers and decision makers in the rearing practice of their underfives.

\section{REFERENCES}

1. Staf Pengajar IKA FKUI. Buku Kuliah Ilmu Kesehatan Anak, ed.4 Jakarta: Bagian IKA FKUI, 1985.

2. Utomo B. Child survival. 1st ed. Yogyakarta: Gadjah Mada University Press 1988: 162-88.

3. Ware M. Child survival. $1^{\text {st }}$ ed. Yogyakarta: Gajah Mada University Press 1988: 257-300.

4. Sularyo TS. Child health care with emphasis on childhood morbidity and mortality problems. Presented at the 11 th Asian Medical Student Conference, Jakarta, 1989.

5. Pechevis M. Determinants for optimal child growth and development. Presented at the KONIKA V (5th National Congress of Pediatrics), Medan, 1981.

6. Sularyo TS, Sudjarwo SR, Napitupulu P, Walandau NS, Sugiono M. Child rearing practice and psychomotor development in rural and urban areas in Jakarta. Presented at the KONIKA VI (6th National congress of Pediatrics), Denpasar Bali, 1984.

7. Morley D, Lovel H. My name is today; 1st ed. London: Mac Millan, 1986; 84-93, 308-12.

8. BPS (central bureau of statistics). Indonesian Statistics 1986. Jakarta: BPS, 1986.

9. Sularyo TS. Population, family planning and child health. Material for growth and development and social pediatrics 
textbook. Surabaya : UKK Tumbuh Kembang-Pediatri Sosial, 1994.

10. Unicef. Development goals and strategies for children in the 1990s. New York: Unicef, 1990: 25-30.
11. Health Profile in Indonesia. Jakarta : Pusat Data Kesehatan; 1992: 31-8.

12. WHO. Breastfeeding and child spacing. International Child Health, 1993; 4: 37-40. 